\title{
THE EFFECT OF BANK CHARACTERISTICS AND GOVERNANCE ON THE RATE OF RETURN IN ISLAMIC RURAL BANK
}

\author{
Rozaq M. Yasin \\ Management Study Program, Muria Kudus University, Indonesia \\ rozaq.yasin@umk.ac.id
}

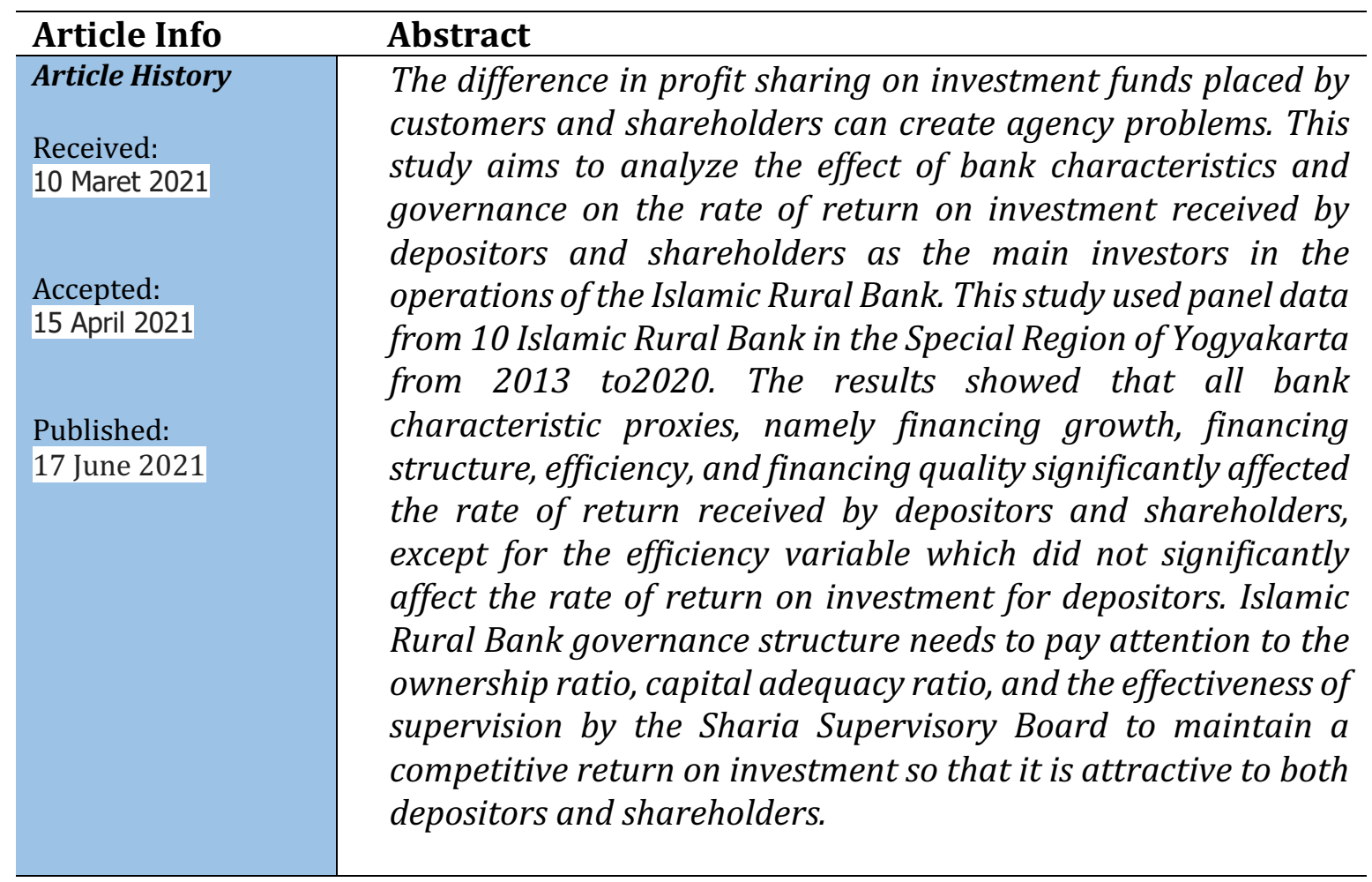

Keywords: rate of return, bank characteristics, governance.

\section{INTRODUCTION}

The return instrument is used by the Islamic Rural Bank (BPRS) in the distribution of profits on funds placed by depositors and shareholders as the main funders. Bank management needs to put in place certain retention policies to keep their main lenders from leaving. The rate of return received by customers can be seen from the ratio of return on mudharabah deposit (ROMD), while the return on investment for shareholders can be seen from the ratio of return on equity (ROE). The comparison of ROMD and ROE values can be seen in Figure 1. 
Figure 1. The Comparison of ROE and ROMD of Islamic Rural Bank in Indonesia

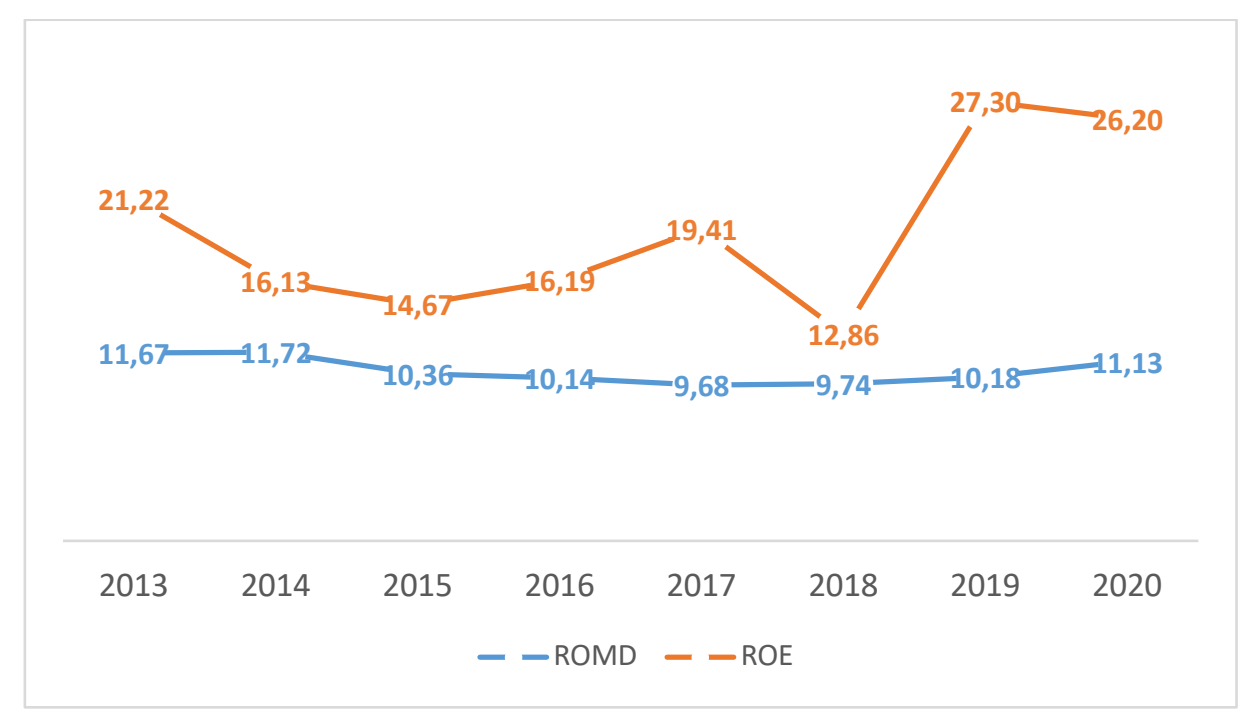

Source: Sharia Banking Statistics OJK, 2020

Figure 1 depicts that the ROE, which is always higher than the ROMD, indicates that the concept of return on investment is considered incomplete where the proportion of funds from depositors is much larger than that of shareholders, but the return on investment given to depositors is smaller. This condition can lead to unfairness deviating from the Islamic Economic Framework (Saraswati \& Tohirin, 2018). Jensen and Meckling (1976) state that when a firm (in this case the Islamic Rural Bank) is owned by several people who influence the policies and sustainability of the company, problems will arise, especially regarding the distribution of results as seen from the ROMD and ROE values.

This practice triggers agency problems among management, shareholders, and depositors. The company's management tries to maximize the return on investment for its shareholders so that the management position is not displaced (Fama, 1980). On the other hand, customer management also needs to maintain the rate of return on investment so they will not withdraw their funds.

This study was carried out to see whether the characteristics of the bank namely financing growth, financing structure, efficiency, non-performing financing ratio, and governance structure seen from the ownership concentration, minimum capital requirement, number of shareholders, and the number of Sharia Supervisory Boards affect the returns received by the depositors and shareholders of the BPRS in the Special Region of Yogyakarta. The Special Region of Yogyakarta was chosen since the development of the e Islamic Rural Bank was quite good. There were also significant differences in the practice of distributing mudharabah (profit-sharing), some were able to distribute profit-sharing reaching $50 \%$ of the total financing disbursed. Mudharabah maintains the spirit of the establishment of Islamic banking. 
The systematic writing of this research is divided into three parts. First, to explain the background and literature review related to investment returns. Second, the research method. Third, the findings in the research and the conclusions, suggestions, and implications of the research.

\section{LITERATURE REVIEW}

Jensen dan Mackling (1976) describe that agency relationships emerge when one or more individuals (principals) hire another individual (agent) to provide a service and then delegate power to agents to make decisions on behalf of the principal. This theory states that the company's capital structure should have an adequate portion of the debt (savings/deposits) since debt is a control mechanism against the tendency of managers to behave opportunistically (Jensen \& Mackling, 1976).

The operation of the BPRS is closely related to this agency theory where shareholders and depositors both entrust their funds to be managed by the BPRS as an agent. BPRS as agents should carry out good corporate governance as a form of responsibility to the principal (shareholders and depositors). This theory can be understood that as long as the funds collected from the community (DPK) are still large, the portion of third-party financing (TPF) can be increased. However, if the cost to manage TPF is greater than the profit received, it is better to avoid adding TPF because it will increase the burden of return on investment for depositors.

Previous studies revealed that customer behavior in choosing Islamic banks is driven by the return on investment obtained (Hamza, 2015; Hasanah et al., 2013). This means that the more competitive the return on investment offered by the BPRS, the greater the public's interest in depositing their funds. On the other hand, the shareholders of a BPRS ideally demand a high return on investment as seen from the value of the ROE. This ratio relates to the bank's ability to provide dividends to its shareholders. The low ROE can endanger the position of management in the eyes of shareholders because they are considered unable to run the company's business properly. As a result, management tries as much as possible to keep the company in good condition and promises to its shareholders so that the management is not replaced by shareholders (Jensen dan Mackling, 1976).

The percentage of ROMD and ROE in a BPRS can be influenced by many things, including 1) organizational structure, good organizational health, and budget achievements, 2) the condition of the firm by looking at the financial performance and risk profile of the bank across time, and 3) macroeconomic conditions by taking into account the existing government/regulatory policies, inflation, and interest rates. In addition, various categories of shareholders have different 
attitude profiles in dealing with business risks (Srairi, 2013). Depositors in Muslim countries in Asia assume that the ownership concentration affects the return on investment (Hamza, 2015).

The assessment of financial performance is very important to reveal whether resources are used optimally to adapt the environmental changes (Arfiani \& Mulazid, 2017). This leads to income and returns on investment that BPRS can offer. The financial performance and risk profile were taken by the BPRS are considered to reflect the effect on the investment returns of depositors and shareholders (Ardana \& Wulandari, 2018; Novianti et al., 2016; Nur \& Nasir, 2014; Ramlan \& Adnan, 2016). The characteristics of the bank, as well as the governance system, may affect the rate of return provided by a BPRS as seen in the research framework in Figure 2.

Figure 2. Research Framework

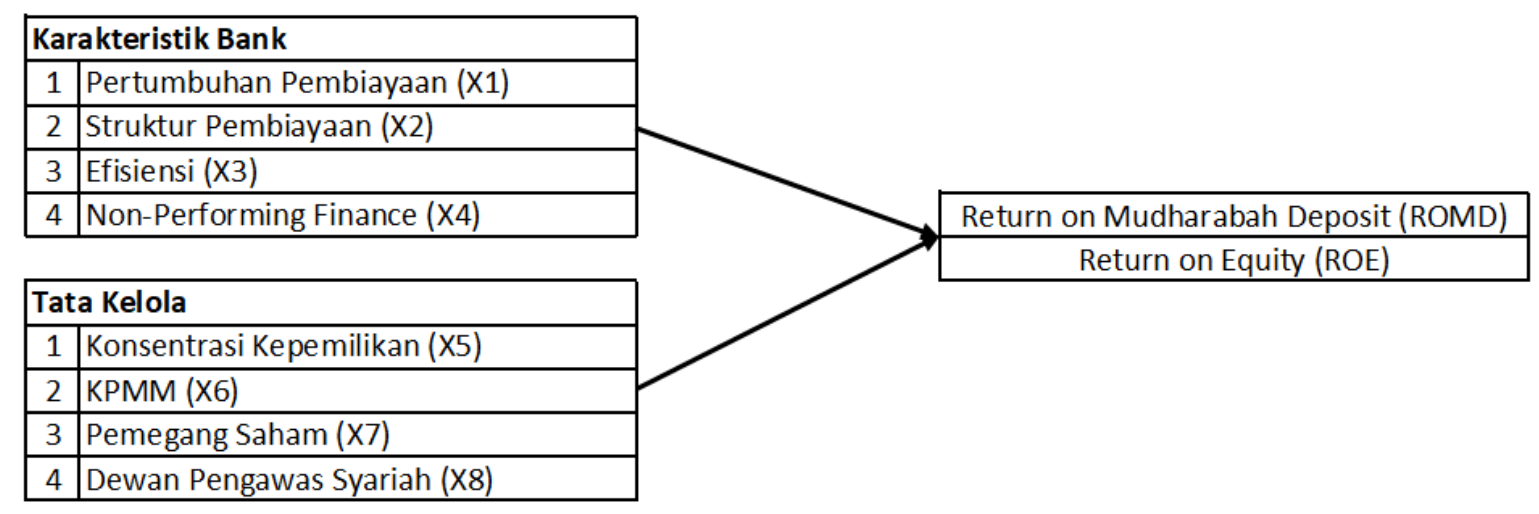

\section{METHOD}

The competitive rate of return on investment is an indicator of the characteristics and governance of the bank. Thus, this study took a sample of 10 BPRS using purposive sampling. They are 1) BPRS Mitra Amal Mulia; 2) BPRS Mitra Harmoni Yogyakarta; 3) BPRS Formes; 4) BPRS Mitra Cahaya Indonesia; 5) BPRS Madina Mandiri Sejahtera; 6) BPRS Danagung Syariah; 7) BPRS Margi Rizki Bahagia; 8) BPRS Bangun Drajat Warga; 9) BPRS Dana Hidayatullah; 10) BPRS Barokah Dana Sejahtera. The data used is semi-annual panel data from 2013 to 2020.

This study employed secondary data that is quantitative. The data collection technique was carried out by the documentation method where data was collected from published reports accessed from http://cfs.ojk.go.id. Table 1 is the definitions and measurements of the variables of this study.

Data analysis was carried out using a data panel regression using the following two equations:

$$
\begin{aligned}
R O E_{i t}=\beta_{0}+ & \beta_{1} F G_{1 i t}+\beta_{2} P L S_{2 i t}+\beta_{3} B O P O_{3 i t}+\beta_{4} N P F_{4 i t}+\beta_{5} P S P_{5 i t} \\
& +\beta_{6} K P M M_{6 i t}+\beta_{7} T P S_{7 i t}+\beta_{8} D P S_{8 i t}+e_{i t}
\end{aligned}
$$




$$
\begin{aligned}
R O M D_{i t}=\beta_{0} & +\beta_{1} F G_{1 i t}+\beta_{2} P L S_{2 i t}+\beta_{3} B O P O_{3 i t}+\beta_{4} N P F_{4 i t}+\beta_{5} P S P_{5 i t} \\
& +\beta_{6} K P M M_{6 i t}+\beta_{7} T P S_{7 i t}+\beta_{8} D P S_{8 i t}+e_{i t}
\end{aligned}
$$

Rate of Return

Mudharabah Deposit

Return on Capital

\begin{tabular}{|c|c|c|c|}
\hline No & Variable & Definition & Measurement \\
\hline \multirow[t]{6}{*}{1} & \multicolumn{3}{|c|}{ Dependent Variable } \\
\hline & \multicolumn{3}{|c|}{ Rate of Return } \\
\hline & \multirow[t]{2}{*}{ ROMD } & Mudharabah Deposit & \\
\hline & & & Annual Equivalent Rate (\%) \\
\hline & \multirow{2}{*}{ ROE } & \multirow[t]{2}{*}{ Return on Capital } & Net Profit \\
\hline & & & $\overline{\text { Total Capital }}$ \\
\hline \multirow[t]{5}{*}{ II } & \multirow{2}{*}{\multicolumn{2}{|c|}{ Independent Variable }} & \\
\hline & & & Total Financing $_{t}-$ Total Financir \\
\hline & \multirow{7}{*}{$\begin{array}{c}\text { Bank } \\
\text { Characteristics }\end{array}$} & Financing Growth & Total Financing $\mathrm{t}_{\mathrm{t}-1}$ \\
\hline & & \multirow{2}{*}{ Financing Structure } & SyirkahFinancing \\
\hline & & & $\overline{\text { Total Financing }}$ \\
\hline \multirow{4}{*}{$\mathrm{a}$} & & \multirow{2}{*}{ Efficiency (BOPO) } & Operating expenses \\
\hline & & & $\overline{\text { Operating Income }}$ \\
\hline & & \multirow{2}{*}{$\begin{array}{l}\text { Non-Performing Finance } \\
\text { (NPF) }\end{array}$} & Non-performing financing \\
\hline & & & Total Financing \\
\hline \multirow{5}{*}{$\mathrm{b}$} & \multirow{5}{*}{ Governance } & Ownership Concentration & $\begin{array}{l}\text { Percentage of ownership based on } \\
\text { the largest shareholder of the } \\
\text { bank. }\end{array}$ \\
\hline & & Minimum Capital & Total Capital \\
\hline & & Requirement & $\overline{\text { Risk-weighted Assets }}$ \\
\hline & & Shareholders & Number of Shareholders \\
\hline & & Sharia Supervisory Board & $\begin{array}{l}\text { Number of Sharia Supervisory } \\
\text { Board }\end{array}$ \\
\hline
\end{tabular}

Table 1. Operational Definition of Variables

Researchers need to choose the best estimation model among common effects, fixed effects, and random effects by conducting the Chow test, Hausman test, and Lagrange Multiplier test. After that, this study tested whether there was a correlation and difference between the rate of return on investment received by depositors and shareholders using the paired sample t-test for the average difference. 


\section{RESULTS AND DISCUSSION}

\section{Descriptive Analysis}

Table 2. Statistical Properties of Variables (10 BPRS - 2013:2020)

\begin{tabular}{|lccccc|}
\hline Variable & Mean & Median & Max & Min & Std. Dev. \\
\hline ROE & 19.02 & 17.87 & 84.42 & $(239.96)$ & 32.12 \\
ROMD & 8.24 & 8.36 & 13.13 & 1.43 & 2.16 \\
FG & 22.33 & 14.95 & 311.88 & $(72.23)$ & 39.36 \\
PLS & 21.75 & 17.36 & 58.76 & 0.23 & 16.95 \\
BOPO & 87.56 & 86.09 & 178.85 & 2.83 & 20.37 \\
NPF & 8.73 & 7.38 & 34.98 & - & 5.72 \\
PSP & 54.42 & 48.54 & 99.93 & 21.00 & 24.36 \\
KPMM & 18.23 & 16.05 & 80.73 & 5.00 & 10.26 \\
TPS & 6.99 & 8.00 & 10.00 & 2.00 & 3.01 \\
DPS & 2.09 & 2.00 & 3.00 & 1.00 & 0.34 \\
\hline
\end{tabular}

Source: Processed Data, 2021

Table 2 shows the average ROE (19.02\%) which is much higher than the average ROMD $(8.24 \%)$ indicates that there is a gap between ROMD and ROE in the distribution of BPRS profit. This is not in accordance with the Profit Loss Sharing paradigm where the agency relationship between depositors and banks has similar features with the relationship between shareholders and banks in terms of risk, rights, and governance structure (Hamza, 2015). The rate of return on investment received by the two is different. The average financing growth of $22.33 \%$ with an NPF level of $8.73 \%$ indicates that the BPRS is trying to maintain its financing growth trend so that its NPF ratio is maintained. Even though according to regulation, the NPF value is still above $5 \%$ as recommended.

The striking difference in the financing structure of the profit-sharing of inter-BPRS is indicated by the high standard deviation value (16.95\%) indicating the difference in courage in showing the identity of the Sharia BPR in distributing profit-sharing-based financing. The higher the value of the profit-sharing financing structure indicates that the BPRS shows the spirit of developing its sharia economy through profit-sharing instruments and vice versa. The average Minimum Capital Requirement of 18.23\% indicates a fairly high level of solvency owned by BPRS. On average, there are two DPS owned by BPRS. It does not follow the recommendation from IFSB-3 which suggesting the minimum number of DPS is three people. The different total shareholders also indicate that some BPRS are subsidiaries, where the controlling shareholder is the group/holding company. 
The results of the multicollinearity test show the correlation results of no value more than 0.8. This means that this research is free from multicollinearity problems between independent variables as shown in Table 3.

Table 3. Multicollinearity Test Results

\begin{tabular}{|lcccccccc|}
\hline & FG & PLS & BOPO & NPF & PSP & KPMM & TPS & DPS \\
\hline FG & 1.00 & & & & & & & \\
PLS & -0.13 & 1.00 & & & & & & \\
BOPO & 0.03 & 0.01 & 1.00 & & & & & \\
NPF & -0.27 & 0.28 & 0.41 & 1.00 & & & & \\
PSP & 0.19 & -0.32 & 0.18 & -0.08 & 1.00 & & & \\
KPMM & -0.09 & -0.03 & -0.35 & 0.01 & -0.11 & 1.00 & & \\
TPS & -0.26 & 0.16 & -0.24 & 0.06 & -0.73 & 0.03 & 1.00 & \\
DPS & -0.07 & -0.30 & 0.09 & 0.06 & -0.14 & 0.08 & 0.31 & 1.00 \\
\hline
\end{tabular}

Source: Eviews 10 Processed Data, 2021

\section{Regression Analysis}

Based on the selection test of data panel regression, in the ROMD equation regression, the better model to use is the fixed effect. Meanwhile, the regression model of the ROE equation that is better used is the random effect. The regression estimation results of the ROMD and ROE equations can be written as follows:

$$
\begin{gathered}
R O E_{i t}=\beta_{0}+0,12 F G_{1 i t}-0,41 P L S_{2 i t}-0,24 B O P O_{3 i t}-2,08 N P F_{4 i t}-0,38 P S P_{5 i t} \\
-0,39 K P M M_{6 i t}+19,47 D P S_{8 i t}+e_{i t}
\end{gathered}
$$

$$
\begin{gathered}
R O M D_{i t}=12,99+0,006 F G_{1 i t}+0,024 P L S_{2 i t}-0,17 N P F_{4 i t}-0,11 K P M M_{6 i t} \\
-0,59 T P S_{7 i t}+1,41 D P S_{8 i t}+e_{i t}
\end{gathered}
$$

\begin{tabular}{|c|c|c|c|c|c|}
\hline \multirow[t]{2}{*}{ No. } & \multirow[t]{2}{*}{ Independent Variable } & \multicolumn{2}{|c|}{$\begin{array}{c}\text { Dependent Variable } \\
\text { ROMD }\end{array}$} & \multicolumn{2}{|c|}{$\begin{array}{c}\text { Dependent Variable } \\
\text { ROE }\end{array}$} \\
\hline & & Coefficient & Description & Coefficient & Description \\
\hline \multirow{4}{*}{1} & Financing Growth (FG) & 0.005 & Significant* & 0.12 & Significant* \\
\hline & Financing Structure (PLS) & 0.024 & Significant* & -0.41 & Significant* \\
\hline & Efficiency (BOPO) & -0.003 & $\begin{array}{c}\text { Not } \\
\text { Significant }\end{array}$ & -0.24 & Significant* \\
\hline & Non-performing Loan (NPF) & -0.165 & Significant* & -2.08 & Significant* \\
\hline
\end{tabular}

Table 4 presents a summary of the regression results of the two ROMD and ROE equations.

Table 4. Summary of ROMD and ROE Regression Equations Results 


\begin{tabular}{|c|c|c|c|c|c|}
\hline \multirow{4}{*}{2} & $\begin{array}{l}\text { Controlling shareholders } \\
\text { (PSP) }\end{array}$ & -0.009 & $\begin{array}{c}\text { Not } \\
\text { Significant }\end{array}$ & -0.38 & Significant* \\
\hline & $\begin{array}{l}\text { Minimum Capital } \\
\text { Requirements (KPMM) }\end{array}$ & -0.11 & Significant* & -0.39 & Significant* \\
\hline & Total Shareholders (TPS) & -0.59 & Significant* & 0.50 & $\begin{array}{c}\text { Not } \\
\text { Significant }\end{array}$ \\
\hline & $\begin{array}{l}\text { Number of Sharia } \\
\text { Supervisory Board (DPS) }\end{array}$ & 0.02 & Significant* & 19.47 & Significant* \\
\hline \multicolumn{2}{|c|}{ Adjusted R-Squared } & & 0.731 & & 0,568 \\
\hline \multicolumn{2}{|c|}{ Prob(F-Statistics) } & & 0.0000 & & 0.0000 \\
\hline
\end{tabular}

Description: ***) Sig $\alpha<1 \%$;*) Sig $\alpha<5 \%$; *) Sig $\alpha<10 \%$

Source: Eviews 10 Processed Data, 2020

\section{DISCUSSION}

\section{Bank Characteristics}

The characteristics of a BPRS that operate based on the principle of profit-sharing in funding and financing show the aspect of fairness in transactions. The values of togetherness to gain profits and avoid speculative activities are the advantages of BPRS. In looking at the characteristics of the BPRS, this study used the proxies of the value of financing growth, financing structure, business efficiency, and the ratio of non-performing financing (NPF). The results show that all proxies of bank characteristics significantly affect the return on investment received by depositors and shareholders, except for the variable of efficiency which does not significantly affect investment returns for depositors.

The financing growth significantly affects the return on investment since the main income of the BPRS is from the disbursed financing. The high financing disbursed followed by good quality financing makes the return on investment more competitive. The profit-sharing financing structure that is characteristic of Islamic financial products Ismail \& Tohirin, (2010) also has a significant positive effect on investment returns. The increase in financing based on profit-losssharing, despite having the risk of loss, contribute positively to increasing investment returns Ahmed, (2002) for depositors and shareholders.

The efficiency carried out by the BPRS only affected the rate of return on investment for shareholders (Nur \& Nasir, 2014). These results indicate that in the distribution of profits, banks add certain costs that reduce their income. However, they still maintain investment returns for their depositors so that they do not withdraw their funds. In addition, the quality of financing in this study showed a significant negative value (Amelia \& Hardini, 2017; Arfiani \& Mulazid, 2017). It shows that management is trying hard to maintain the quality of its financing so that the 
management position is not displaced as well as maintaining a competitive rate of return on investment for the main funders (Fama, 1980).

\section{Governance}

The percentage of shares owned by the shareholder only affects the return on investment received by the shareholders. This indicates that the ownership ratio of the BPRS as one of the parties that oversee the company's performance in controlling and supervising every decision and policy of the management of the BPRS can significantly maintain good governance of the BPRS industry in safeguarding the rights of shareholders. According to the agency theory proposed by Jensen \& Meckling, (1976), in general, a manager is trying harder to increase profits to keep the dividends that can be given so that the manager's position is not replaced.

On the other hand, the minimum capital requirement for a BPRS significantly affects investment returns. Minimum capital requirement, which is an indicator of a bank's ability to cover a decrease in its assets as a result of bank losses caused by risky assets Amri \& Oviza (2018) can be fulfilled properly to maintain the return on investment of the BPRS.

BPRS' good governance structure shows that the fewer the number of shareholders, the more competitive the return on investment offered is. A BPRS with a group/holding company shows better performance in maintaining its investment returns. The supervisory function carried out by the Sharia Supervisory Board also shows positive results in maintaining investment returns for depositors and shareholders. This decision is quite appropriate considering that a good corporate governance model is a company oriented towards protecting the rights of all bank stakeholders even though they do not own shares in the company (Abdul-Rahman et al., 2014).

The contribution of third-party capital which is much larger than the capital contribution from shareholders indicates many problems in profit sharing. This is considered as unfairness. Unfair distribution of profits is certainly not in accordance with the concept that is justified in the framework of Islamic law and economics related to the principles of justice and equity (Ismail \& Tohirin, 2010).

\section{CONCLUSION}

Despite the concept of a BPRS follows the profit and loss sharing paradigm, to maintain the trust of stakeholders, banks try to provide a competitive rate of return on investment so that their main funder does not leave. The results show that all bank characteristics used in this study, namely financing growth, financing structure, efficiency, and financing quality significantly affect the return on investment received by depositors and shareholders, except for the variable of efficiency which does not significantly affect investment returns for depositors. 
The governance structure of a BPRS needs to pay attention to the ownership ratio, capital adequacy ratio, and the effectiveness of supervision by the Sharia Supervisory Board to maintain a competitive rate of return on investment to attract depositors and shareholders. The results also show that the large difference in return on investment between depositors and shareholders indicates an unfairness within the framework of the profit and loss sharing paradigm which is the advantage of Islamic banking.

The recommendation from the results of this study is that the BPRS the Special Region of Yogyakarta needs to create characteristics and good and healthy governance that will impact the increasingly competitive rate of return on investment to be offered to depositors and shareholders. A competitive profit-sharing rate will make the BPRS compete not only with conventional banks but also with other Islamic commercial banks.

In addition, it is necessary to review whether to include independent supervisors from the depositors to participate in the process of determining the bank's business plan that has an impact on governance, performance, risk, and investment returns that management can provide. This is because there are concerns that the management has a strong tendency to be more encouraged in channeling financing to high-risk sectors due to fluctuating returns on investment for depositors. This means that when the company only earns a small income, the return on investment is also small.

\section{REFERENCES}

Abdul-Rahman, A., Abdul Latif, R., Muda, R., \& Abdullah, M. A. (2014). Failure and potential of profit-loss sharing contracts: A perspective of New Institutional, Economic (NIE) Theory. Pacific-Basin Finance Journal, 28, 136-151. https://doi.org/10.1016/j.pacfin.2014.01.004

Ahmed, H. (2002). A Microeconomic Model of an Islamic Bank (Issue 59). Islamic Development Bank, Islamic Research and Training Institute.

Amelia, E., \& Hardini, E. F. (2017). Determinant of Mudharabah Financing: A Study at Indonesian Islamic Rural Banking. Etikonomi, 16(1), 43-52. https://doi.org/10.15408/etk.v16i1.4638

Amri, A., \& Oviza, Y. C. (2018). Analisis Risiko dan Pengembalian Hasil Terhadap Pembiayaan Mudarabah Pada Bank Pembiayaan Rakyat Syariah (BPRS). AKBIS, 141-150.

Ardana, Y., \& Wulandari, W. (2018). Tingkat Suku Bunga, Kinerja Keuangan, dan Bagi Hasil Deposito Pada Perbankan Syariah. Esensi: Jurnal Bisnis Dan Manajemen, 8(2), 177-186. https://doi.org/10.15408/ess.v8i2.8392

Arfiani, L. R., \& Mulazid, A. S. (2017). Analisis Faktor-Faktor Yang Mempengaruhi Tingkat Bagi Hasil Simpanan Mudharabab Pada Bank Umum Syariah Indonesia Studi Kasus Pada Bank Umum Syariah di Indonesia Periode 2011-2015. Iqtishodia Jurnal Ekonomi Dan Perbankan Syariah, 4. 
74 Yasin, R. M., The Effect of Bank Characteristics and Governance on The Rate of Return...

Fama, E. F. (1980). Agency Problems and the Theory of the Firm. Journal of Political Economy, 88(2), 288-307.

Hamza, H. (2016). Does Investment Deposit Return in Islamic Banks Reflect PLS Principle. Borsa Istanbul Review, 16(1), 32-42.

Hasanah, H., Azam Achsani, N., Ascarya, A., \& Siregar, H. (2013). Displaced commercial risk: Empirical analysis on the competition between conventional and islamic banking systems in Indonesia. American-Eurasian Journal of Sustainable Agriculture, 7(4), 405-412.

Ismail, A. G. b., \& Tohirin, A. (2010). Islamic law and finance Humanomics, Vol. 26 No. 3, pp. 178-199. Humanomics, 26(3), 178-199.

Jensen, M. C., \& Meckling, W. H. (1976). Theory of The Firm: Managerial Behaviour, Agency Cost and Ownership Structure. Journal of Financial Economics 3 (1976) 305-360, 3. https://doi.org/10.1177/0018726718812602

Novianti, N., Badina, T., \& Erlangga, A. (2016). Analisis pengaruh Return On Asset (ROA), Biaya Operasional Terhadap Pendapatan Operasional (BOPO), Suku Bunga, Financing To Deposits Ratio (FDR) Dan Non Performing Financing (NPF) Terhadap Tingkat Bagi Hasil Deposito Mudharabah (Studi Empiris pada Bank UM. Esensi: Jurnal Bisnis Dan Manajemen, 5(1), 65-86. https://doi.org/10.15408/ess.v5i1.2333

Nur, M. I., \& Nasir, M. (2014). Pengaruh Kinerja Keuangan Terhadap Tingkat Bagi Hasil Deposito Mudharabah Dan Tingkat Pengembalian Ekuitas Pada Bank Umum Syariah Di Indonesia. Diponegoro Journal of Accounting, 3, 266-278.

Ramlan, H., \& Adnan, M. S. (2016). The Profitability of Islamic and Conventional Bank: Case Study in Malaysia. Procedia Economics and Finance, 35(October 2015), 359-367. https://doi.org/10.1016/s2212-5671(16)00044-7

Srairi, S. (2013). Ownership structure and risk-taking behaviour in conventional and Islamic banks: Evidence for MENA countries. Borsa Istanbul Review, 13(4), 115-127. https://doi.org/10.1016/j.bir.2013.10.010 